\title{
Afrikanerliberalisme in die tydperk 1775 - 1975 - die interpretasies van GD Scholtz en H Giliomee
}

\author{
PDE KLERK $K^{1}$
}

\section{Abstract}

Two historians, GD Scholtz and H Giliomee, have written extensively about liberal political thought among Afrikaners during the period 1775-1975. Their interpretations of the influence of liberalism on Afrikaner political thought differ from one another in some respects. Scholtz acknowledges the influence of the political ideas of the Enlightenment on the Cape Patriot movement of the late eighteenth century, but does not regard these ideas as a form of liberalism. He views liberalism as a political ideology alien to the Afrikaners, that was introduced to South Africa in the early 1800s by British officials and missionaries. Since the middle of the nineteenth century the main exponents of liberal political thought in South Africa were British colonists and their descendants. There were always a few Afrikaners with liberal political ideas, but they were strongly influenced by British culture or by English-speaking South Africans. Giliomee, however, is of the opinion that there were already Afrikaners with liberal ideas at the beginning of the nineteenth century. It appears from his study that, although none of the major Afrikaner political leaders from the eighteenth century until the present can be described as a liberal, in the course of two centuries a number of politicians and intellectuals with an Afrikaans background played an important role in various liberal political movements and had a significant influence on the development of Afrikaner political thought. Although Scholtz and Giliomee have both made an important contribution to research on Afrikaner liberal political thought, it is clear that more research should lead to a better understanding of this phenomenon.

Keywords: South African Historiography; Afrikaner Political Thought; GD Scholtz; H Giliomee; Liberalism; Democracy; Cape Patriot Movement; Cape Franchise; Segregation; Apartheid.

Disciplines: Political History, Intellectual History, Political Philosophy.

\section{Executive summary}

Afrikaner liberalism in the period 1775 - 1975 - the interpretations of GD Scholtz en H Giliomee

The European Enlightenment had a significant influence on the Dutch or Afrikaner settlers of the Cape Colony, who already agitated for political rights during the late eighteenth century. In the course of the next two centuries there were a number of Afrikaner politicians and intellectuals with liberal political views. Only a few historians have made significant contributions to the study of political liberalism among the Afrikaners. They include GD Scholtz (1905-1983) and H Giliomee (born 1938), who are regarded by authoritative scholars of South African historiography as prominent Afrikaner historians. Both have written comprehensively on the political history of the Afrikaners, and especially on the development of their political ideas. Although Scholtz

1 Vakgroep Geskiedenis, Noordwes-Universiteit (Vaaldriehoekkampus). 
and Giliomee's publications are only partly based on a study of original documents, a comparative review of these texts makes it possible to obtain reliable information on the general development and characteristics of political liberalism among Afrikaners. Both historians were influenced by Afrikaner nationalism, but Scholtz belongs to an older generation of Afrikaner historians, while Giliomee has been influenced by historians with various philosophical and ideological backgrounds. A comparitative examination of their studies, as attempted in this article, reveals some important differences between their interpretations and provides guidelines about issues on which more research should be done.

Scholtz and Giliomee both discuss the political ideas underlying the Cape Patriot movement of $1775-1795$, but Giliomee emphasizes that the Patriots were primarily concerned with local issues and only used the ideas of the Enlightenment to further their aims. They agree that the ideas propagated by the leaders of the French Revolution had only a limited influence on the farmers in the eastern districts of the colony. In 1795 these farmers proclaimed their independence from the Dutch India Company, which controlled the colony during this period.

Scholtz and Giliomee both argue that the Cape liberal tradition of the nineteenth century had a significant influence on the Afrikaners. Scholtz regards this as the result of British influence on the Dutch- (or Afrikaans-) speaking colonists, but Giliomee points out that already at the beginning of the nineteenth century, before English-speaking liberals such as John Philip and John Fairbairn propagated liberal views, prominent colonial officials of Dutch extraction, inter alia JA Truter and Andries Stockenström, were in favour of a more liberal policy towards the slaves and the indigenous inhabitants of the colony. Scholtz and Giliomee both state that, with the introduction of a representative parliamentary body in the Cape Colony in 1853, the Afrikaans-speakers of the western districts were in favour of low franchise qualifications, which would give the vote to a substantial number of coloured and black inhabitants, while the Englishspeaking settlers of the eastern districts wanted higher qualifications, which would exclude almost all colonial subjects who were not of European descent. During the late nineteenth century JH Hofmeyr (also known as Onze Jan) was the leader of the Afrikerbond and a very powerful political figure in the Cape Colony. Scholtz and Giliomee both discuss his political ideas, but while Scholtz is of the opinion that his views were influenced by liberalism, Giliomee concludes that he should not be regarded as a liberal politician.

Scholtz and Giliomee agree that, although the constitutions of the two Boer Republics (the Orange Free State and Transvaal) were based on liberal ideas, none of the Boer leaders display the essential characteristics of political liberalism.

Scholtz regards JH Hofmeyr (junior) as the most important liberal political leader in the Union of South Africa before 1948. He writes that Hofmeyr's views influenced the socalled "verligte" (enlightened) politicians of the National Party of the 1960s and 1970s. According to Giliomee Hofmeyr was an influential political liberal, but he points out that his fellow-Afrikaner FS Malan was also an important liberal politician during the period before 1948. He does not regard the "verligte" members of the National Party as liberals, because they were only in favour of limited political reforms that would not endanger the dominant position of the white population. Intellectuals and writers such as Ben Marais, Johannes Degenaar, Jan Rabie and André Brink were the major Afrikaansspeaking proponents of political liberalism during the period of National Party rule.

Although Scholtz acknowledges the influence of the political ideas of the Enlightenment on the Cape Patriot movement of the late eighteenth century, he views liberalism as a political ideology alien to the Afrikaners, that was introduced to South Africa in the 
early 1800 s by British officials and missionaries. According to Scholtz the main exponents of liberal political thought in South Africa were British colonists and their descendants. There were always a few Afrikaners with liberal political ideas, but they were strongly influenced by British culture or by English-speaking South Africans. Scholtz's interpretation is strongly influenced by Afrikaner nationalism, but his view that liberalism should be associated with British influence is shared by some prominent English-speaking scholars of the liberal school of historical writing, who blame race discrimination and denial of political rights to black people on the nationalist and conservative political views of the Afrikaners as the dominant group in South Africa for most of the twentieth century. However, recent historians have pointed out that British colonial policy in South Africa was in many respects not a liberal policy. Furthermore, Giliomee's study shows that, although the major poltical leaders of the Afrikaners since 1775 did not have liberal views, there was always a small group of Afrikaners who propagated and tried to implement liberal political ideas.

\section{Inleiding}

In 1977 het 'n publikasie verskyn met die titel Afrikaner-liberalisme. Daarin spreek 'n aantal akademici hul kommer daaroor uit dat al meer Afrikaners hulle met liberale politieke beskouinge vereenselwig. ${ }^{2}$ Een van die akademici, die historikus GD Scholtz, is ook die outeur van ' $n$ uitgebreide werk oor die ontwikkeling van die Afrikaanse politieke denke, waarin hy onder meer die rol wat die liberalisme as ideologie of denkstroming daarin gespeel het, behandel. ${ }^{3}$ In 'n latere publikasie het 'n ander historikus, Hermann Giliomee, ook ruim aandag gegee aan liberale politieke denke onder Afrikaners. ${ }^{4}$ Albei skrywers het oorspronklike bronnestudie gedoen maar ook gebruik gemaak van die interpretasies van ander historici. Daar het egter baie min studies verskyn oor besondere bewegings of persone wat ' $\mathrm{n}$ belangrike rol gespeel het in die ontwikkeling van liberale politieke denke onder Afrikaners. ${ }^{5}$ Om ' $n$ geheelbeeld van die ontwikkeling van Afrikaanse liberale politieke denke te verkry, is die werke van Scholtz en Giliomee, ${ }^{6}$ insluitende ander geskrifte waarin hulle oor hierdie onderwerp handel, dus veral van belang.

2 PS Dreyer, “Inleiding: die liberalisme", PS Dreyer (red.), Afrikaner-liberalisme (Arcadia, Boekenhoutuitgewers, 1977), p. 28.

3 GD Scholtz, Die ontwikkeling van die politieke denke van die Afrikaner (Johannesburg, Voortrekkerpers en Perskor, 1967-1984). Die werk bestaan uit 8 bande en beslaan altesaam ongeveer 4600 bladsye.

4 H Giliomee, The Afrikaners; biography of a people (Cape Town, Tafelberg, 2003). Die boek het ongeveer 700 bladsye.

5 Die vernaamstes is: EA Walker, Lord de Villiers and his times; South Africa, 1842-1914 (London, Constable, 1925); A Paton, Hofmeyr (Cape Town, Oxford University Press, 1964); C Beyers, Die Kaapse Patriotte gedurende die laaste kwart van die agtiende eeu en die voortlewing van hul denkbeelde (Pretoria, Van Schaik, 1967; hersiene uitgawe); A du Toit, "The Cape Afrikaners' failed liberal movement, 1850-1870", J Butler, R Elphick \& D Welsh (eds), Democratic liberalism in South Africa; its history and prospect (Middletown, Conn., Wesleyan University Press, 1987), pp. 35-63; FA Mouton, Prophet without honour - FS Malan: Afrikaner, South African and Cape liberal (Pretoria, Protea Boekhuis, 2011).

6 Giliomee se The Afrikaners het, in ietwat verkorte en gewysigde vorm, ook in Afrikaans verskyn: H Giliomee, Die Afrikaners; $n$ biografie (Kaapstad, Tafelberg, 2004). Hoewel daar in die Afrikaanse 
Die oogmerk van die artikel is in die eerste plek om op grond van die geskrifte van Scholtz en Giliomee 'n beeld van die ontwikkeling van Afrikaanse politieke denke oor ' $n$ tydperk van twee eeue te verkry. ' $n$ Vergelyking van hul interpretasies behoort verder na vore te bring oor watter aspekte daar verskille verstaan en oor watter sake meer navorsing nodig is. Daar word nie beoog om hul interpretasies aan deeglike kritiek te onderwerp nie, aangesien dit groter kennis sou vereis as wat in die beperkte aantal relevante geskiedwerke beskikbaar is. Die vernaamste eienskappe van Scholtz en Giliomee as historici, en hul plek binne die ontwikkeling van die Afrikaanse geskiedskrywing, moet egter wel in ag geneem word wanneer hul interpretasies vergelyk en beoordeel word, en daarom word in die volgende afdeling, hieronder, kortliks nagegaan hoe medehistorici hul bydrae en plek binne die SuidAfrikaanse Afrikaanse geskiedskrywing aandui.

Die ontwikkeling en kenmerke van liberale politieke denke onder Afrikaners staan nie los van die geskiedenis van liberale politieke denke in Suid-Afrika as geheel nie, maar hieroor het reeds verskeie wetenskaplike studies verskyn. Scholtz en Giliomee het van dié geskrifte gebruik gemaak. Waar dit ter sake is, word na enkele publikasies verwys wat handel oor aspekte van die breër onderwerp van liberale politieke denke in Suid-Afrika. Aangesien Scholtz nie oor die tydperk na 1975 geskryf het nie, word die resente verlede buite beskouing gelaat.

\section{Scholtz en Giliomee as geskiedskrywers}

Slegs twee wetenskaplikes, FA van Jaarsveld en $\mathrm{K}$ Smith, het oorsigwerke oor die ontwikkeling van die Afrikaanse historiografie tot in die laat twintigste eeu gelewer. Albei beskou GD Scholtz (1905-1983) as 'n belangrike Afrikaanse geskiedskrywer. ${ }^{7}$ Hoewel Scholtz ' $n$ akademies geskoolde historikus was, het hy 'n joernalistieke loopbaan gevolg en was hy van 1960 tot 1970 redakteur van Die Transvaler, mondstuk van die regerende Nasionale Party. Hy het, hoofsaaklik in sy vrye tyd, uitgebreide historiese navorsing gedoen en ' $n$ groot aantal geskiedwerke die lig laat sien. Smith en Van Jaarsveld dui albei as een van Scholtz se vernaamste prestasies aan dat hy die Afrikaner bewus probeer maak het van sy plek binne die groter wêreld en dat hy die Afrikaanse geskiedenis in ' $n$ breër konteks geplaas het. ${ }^{8}$ Hulle wys ook daarop dat sy werke, soos dié van die meeste Afrikaanse historici van daardie tyd, sterk beïnvloed is deur die Afrikanernasionalisme, wat sy bloeityd in die periode van ongeveer 1900 tot 1970 beleef het. $^{9}$

$\mathrm{H}$ Giliomee (gebore 1938) behoort tot ' $\mathrm{n}$ jonger geslag Afrikaanse historici, wat sy vernaamste werke in die periode na 1975 gelewer het. Giliomee, is soos Scholtz, 'n baie produktiewe skrywer, en het ' $n$ hele aantal wetenskaplike geskrifte op die terrein van die

weergawe enkele byvoegings voorkom wat verband hou met die onderwerp van die artikel, raak dit nie die essensie van Giliomee se interpretasie nie en daarom word in die voetnote net na die Engelse weergawe verwys.

$7 \quad$ FA van Jaarsveld, Geskiedkundige verkenninge (Pretoria, Van Schaik, 1974), pp. 84-85; K Smith, The changing past; trends in South African historical writing (Johannesburg, Southern, 1988), p. 80.

8 FA van Jaarsveld, Geskiedkundige verkenninge, p. 84; K Smith, The changing past..., pp. 80-81.

9 K Smith, The changing past..., pp. 80-83; FA van Jaarsveld, Die evolusie van apartheid en ander geskiedkundige opstelle (Kaapstad, Tafelberg, 1979), pp. 90-121. In hierdie werk word Scholtz se bydrae tot die geskiedskrywing uitgebreid bespreek. 
geskiedkunde en die politieke wetenskap gepubliseer. Die oorsigte van Smith en Van Jaarsveld bevat slegs kort verwysings na sy vroeë wetenskaplike bydraes. Giliomee het reeds vroeg in sy loopbaan saam met verskeie Engelstalige Suid-Afrikaanse en buitelandse historici ' $\mathrm{n}$ belangrike sintesewerk oor die geskiedenis van Suid-Afrika voor 1820 gepubliseer. ${ }^{10}$ Volgens Van Jaarsveld het Giliomee hierin nie net die tradisionele Afrikaanse vertolking van die Kompanjiestydperk probeer aftakel nie, maar is hy ook krities oor interpretasies deur historici van die liberale skool. Hy meen dat Giliomee hom by die radikale (of Marxistiese) geskiedskrywers skaar. ${ }^{11}$ Smith skryf dat Giliomee in hierdie werk ' $n$ kompromis tussen die interpretasie van liberale skrywers soos ID MacCrone en die klasse-analise van die radikale historici probeer vind. ${ }^{12}$ Giliomee was aanvanklik as historikus verbonde aan die Universiteit van Stellenbosch en van 1983 tot 1998 professor in Politieke Studies aan die Universiteit van Kaapstad. Sy werk The Afrikaners, wat in 2003 gelyktydig in Suid-Afrika en in die Verenigde State van Amerika (VSA) verskyn het, is deur binnelandse en buitelandse resensente, insluitende Afrikaanse historici, hoog aangeslaan. ${ }^{13}$ Giliomee het hom in sy vroeë jare in Stellenbosch nie as deel van die "Afrikaner nasionalistiese establishment" aan daardie universiteit beskou nie en het later sy kollegas aan die Universiteit van Kaapstad as "net te gerieflik links, liberaal en tevrede met hulself" ervaar. ${ }^{14}$ Hoewel hy, anders as Scholtz, min invloed toon van die Afrikanernasionalisme, kan hy ook nie sonder meer as lid van óf die liberale óf die radikale skool van historici beskou word nie. Sy plek in die Suid-Afrikaanse geskiedskrywing sal eers deur toekomstige wetenskaplikes na waarde geskat kan word..

\section{Liberalisme: enkele algemene opmerkings}

Daar bestaan heelwat verskille onder historici, filosowe en politieke wetenskaplikes oor wat presies onder liberalisme verstaan moet word, maar tog ook 'n groot mate van konsensus ten opsigte van die inhoud en betekenis van hierdie term. Enkele algemene opmerkings, gegrond op resente oorsigwerke, is nodig as agtergrond by die bespreking van Scholtz en Giliomee se interpretasies. Hoewel terme soos ekonomiese liberalisme en godsdienstige liberalisme dikwels gebruik word, word die begrip liberalisme primêr met 'n politieke denkrigting of ideologie verbind. Historici en politieke wetenskaplikes beskou dit oor die algemeen as ' $n$ baie belangrike politieke denkrigting in die moderne Westerse geskiedenis en verwys soms selfs daarna as die dominante ideologie in die huidige Westerse wêreld. ${ }^{15}$

Die term liberalisme is vir die eerste keer vroeg in die negentiende eeu gebruik, en in GrootBrittanje het die Whigparty in die loop van hierdie eeu bekend geword as die Liberale

10 R Elphick \& H Giliomee (eds), The shaping of South African society, 1652-1820 (Cape Town, Longman, 1979).

11 FA van Jaarsveld, Omstrede Suid-Afrikaanse verlede; geskiedenisideologie en die skuldvraagstuk (Johannesburg, Perskor, 1984), pp. 66-67.

12 K Smith, The changing past..., pp. 204-205.

13 J Tempelhoff, "Historia in gesprek met Hermann Giliomee", Historia, 48, 1, 2003, p. 6. In hierdie artikel word ook verdere biografiese besonderhede oor Giliomee verskaf.

14 H Giliomee, soos aangehaal in J Tempelhoff, "Historia in gesprek met Hermann Giliomee", Historia, 48, 1, 2003, p. 10.

15 Byvoorbeeld A Heywood, Political ideologies; an introduction (Basingstoke, Palgrave Macmillan, 2007, fourth edition), p. 25. 
Party. ${ }^{16}$ In resente wetenskaplike werke word egter aanvaar dat die wortels van liberalisme as politieke ideologie veel verder terug in die geskiedenis lê. Liberalisme word gewoonlik verbind met die opkoms van die middelklas of burgery vanaf die laat Middeleeue. Veral in Engeland het die middelklas hom in die sewentiende eeu verset teen die mag van die koning. $\mathrm{Na}$ die Roemryke Rewolusie van 1688 het Engeland en Skotland konstitusionele monargieë geword waarin die mag van die koning beperk is en die parlement, wat gedomineer is deur die verteenwoordigers van die burgery, belangrike politieke regte verwerf het, veral die reg om wette vir die land te maak. John Locke (1632-1704), na wie dikwels as die vader van die liberalisme verwys word, het in sy geskrifte hierdie politieke bedeling teoreties probeer verantwoord. Hy het verklaar dat alle mense sekere natuurregte het, wat insluit die reg op lewe, op vryheid en op die besit van eiendom. Om hierdie regte te beskerm, het gemeenskappe regerings daargestel. 'n Sosiale kontrak is tussen heersers en onderdane gesluit, waarin die magte en regte van beide vasgelê is. Die staat moet so min mag as moontlik hê sodat dit so min as moontlik inbreuk maak op die fundamentele regte van die individu. ${ }^{17}$

Locke word meesal gereken as ' $n$ vroeë denker van die intellektuele beweging wat bekend staan as die Verligting. Verligtingsdenkers soos die baron van Montesquieu en Jean-Jacques Rousseau se beskouinge oor die verhouding tussen owerhede en onderdane het ' $\mathrm{n}$ groot invloed gehad op diegene wat in die Amerikaanse Vryheidsoorlog (1775-1783) en die Franse Rewolusie van 1789 teen hul regeerders in opstand gekom het. Hierdie beskouinge het dan ook ' $n$ neerslag gevind in die grondwet van die VSA en in die Franse Verklaring van die Regte van die Mens en die Burger (1789). ${ }^{18}$ In die loop van die negentiende eeu het die ideologie van liberalisme versprei oor Europa, waar die Industriële Omwenteling gelei het tot ' $n$ aansienlike vergroting van die middelklas. In baie lande het liberale politieke idees en strewes tot die totstandkoming van parlementêre regerings gelei. ${ }^{19}$

In die negentiende eeu het politieke en intellektuele leiers dikwels liberale én nasionale strewes gehad. Hulle wou individuele sowel as nasionale vryheid hê. Ook in lande waar liberale politici reeds in beheer van sake was, was hul soms tegelyk ook nasionaliste. Liberale politieke figure het byvoorbeeld ' $n$ leidende rol gespeel in die Nederlandse nasionalisme van die laat negentiende eeu, wat homself onder meer gemanifesteer het in sterk simpatie met die Boererepublieke in hul stryd teen die Britse Ryk. ${ }^{20}$ In die vroeë twintigste eeu het radikale vorme van nasionalisme, soos die Fascisme en Nasionaal-Sosialisme, egter gelei tot die

16 Vergelyk WP Esterhuyse, PvdP du Toit \& AA van Niekerk (reds.), Moderne politieke ideologieë (Johannesburg, Southern, 1987), p. 39; A Heywood, Political ideologies..., p. 24.

17 Vergelyk PH Kapp et alia, Geskiedenis van die Westerse Beskawing, band 1 (Pretoria, HAUM, 1982), p. 394; LP Baradat, Political ideologies; their origins and impact (Englewood Cliffs, NJ, Prentice-Hall, 2009, tenth edition), pp. 70-77; A Heywood, Political ideologies..., pp. 37-38.

18 In L Marquard, Liberalism in South Africa (Johannesburg, South African Institute of Race Relations, 1965), pp. 2-4, word hierdie verklaring gebruik om die basiese kenmerke van die liberalisme te verduidelik.

19 Vergelyk PH Kapp et alia, Geskiedenis van die Westerse Beskawing, band 2 (Pretoria, HAUM, 1984), pp. 197-217; WP Esterhuyse, PvdP du Toit \& AA van Niekerk (reds.), Moderne politieke ideologieë, p. 96.

20 Vergelyk H te Velde, Gemeenschapszin en plichtsbesef; liberalisme en nationalisme in Nederland, 18701918 ('s-Gravenhage, Sdu, 1992). 
totstandkoming van totalitêre stelsels waar daar byna geen individuele vryhede bestaan het nie en wat dus feitlik die teenoorgestelde van liberale politieke stelsels was. ${ }^{21}$

Al het die hoofelemente van die liberalisme in belangrike mate konstant gebly, het liberale politieke denke tog in die loop van die tyd veranderinge ondergaan. Liberalisme kan beskou word as die vader van die demokrasie, maar algemene volwasse stemreg, soos dit in huidige demokratiese regeringstelsels voorkom, is nie deur die vernaamste liberale denkers van die agtiende en vroeë negentiende eeue voorgestaan nie. Hulle het geglo dat stemreg vir die massa juis liberale waardes sal bedreig. ${ }^{22}$ Veral vanaf die middel van die negentiende eeu is stemreg in die meeste parlementêre state na groter dele van die bevolking uitgebrei. In Brittanje is algemene stemreg vir mans en vroue eers in 1928 ingestel. ${ }^{23}$ Die liberalisme van die agtiende en negentiende eeue, wat meesal klassieke liberalisme genoem word, is onlosmaaklik verbind met die beperking van staatsgesag en minimum inmenging van die staat in die ekonomie. In die twintigste eeu het baie liberale denkers ' $n$ sosiale liberalisme voorgestaan. Dit het gelei het tot die totstandkoming van welsynstate in Wes-Europa, waar daar ' $n$ groot mate van herverdeling van rykdom en staatsinmenging in die ekonomie is, hoewel die ekonomiese stelsels van hierdie lande tog nog as hoofsaaklik vrye markstelsels getipeer kan word. ${ }^{24}$

\section{Die Kaapkolonie in die periode voor 1806}

In die eerste band van Scholtz se studie oor die ontwikkeling van die politieke denke van die Afrikaner, wat handel oor die tydperk voor 1806, word die woord liberalisme feitlik nie gebruik nie. Soos hierbo genoem, het die term eers in die negentiende eeu ontstaan. Scholtz wys daarop dat die naam liberalisme gegee is aan die strewe vanaf die vroeë negentiende eeu om stemreg vir die Britse parlement na groter dele van die bevolking uit te brei. ${ }^{25} \mathrm{Hy}$ erken wel dat die agtiende-eeuse Verligting, soos veral beliggaam in die beskouinge van Rousseau, die politieke denke in Brittanje beïnvloed het. ${ }^{26}$ Volgens Scholtz het liberalisme ook eers vroeg in die negentiende eeu "sy verskyning op Suid-Afrikaanse bodem" gemaak en was dit van suiwer Britse oorsprong. ${ }^{27}$

Scholtz toon aan dat daar in die Nederlandse Republiek van die sewentiende eeu ' $n$ aristokratiese bestuursvorm gegeld het wat seggenskap in die bestuur van die staat in die hande van meer as ' $n$ handjievol persone geplaas het. ${ }^{28}$ Daar was in Nederland meer vryheid

21 Vergelyk WP Esterhuyse, PvdP du Toit \& AA van Niekerk (reds.), Moderne politieke ideologieë, pp. 263-308; LP Baradat, Political ideologies..., pp. 223-258; A Heywood, Political ideologies..., pp. 203229.

22 Vergelyk PH Kapp et alia, Geskiedenis van die Westerse Beskawing, band 2, p.. 197; LP Baradat, Political ideologies..., p. 116; A Heywood, Political ideologies...,p. 41.

23 PH Kapp et alia, Geskiedenis van die Westerse Beskawing, band 2, p. 204.

24 Vergelyk WP Esterhuyse, PvdP du Toit \& AA van Niekerk (reds.), Moderne politieke ideologieë, pp. 96-101; LP Baradat, Political ideologies..., pp. 103-107; A Heywood, Political ideologies...,pp. 56-58.

25 GD Scholtz, Die ontwikkeling..., band 2, p. 167.

26 GD Scholtz, Die ontwikkeling..., band 2, p. 166.

27 GD Scholtz, Die ontwikkeling...,band 2, p. 165.

28 GD Scholtz, Die ontwikkeling...,band 1, pp. 32-33, 249-250. 
vir die individu en groter vryheid van spraak en godsdiens as in ander Europese lande. Die eerste Kaapse koloniste het aanspraak gemaak op dieselfde burgerlike vryhede as die Nederlanders, soos blyk uit die stryd teen goewerneur WA van der Stel in die vroeë agtiende eeu. ${ }^{29} \mathrm{Na}$ die Roemryke Rewolusie van 1688 het Groot-Brittanje die leiding by Nederland oorgeneem ten opsigte van die strewe na vryheid vir die individu en die beperking van die mag van die staat. ${ }^{30}$ Locke en Montesquieu kan, volgens Scholtz, as die geestelike vaders van die Amerikaanse Vryheidsoorlog beskou word. ${ }^{31}$ Die Amerikaanse vryheidstryd het ' $n$ groot invloed in Nederland gehad, waar die Patriottebeweging in die laat agtiende eeu ontstaan het. Hierdie beweging het na die Kaapkolonie versprei, waar in 1778 twee geskrifte die lig gesien het, waaruit blyk dat ook die Afrikaner "geestelike erfgenaam" geword het van die "idee van vryheid wat in Europa en Amerika verkondig is". ${ }^{32}$ Scholtz gee " $n$ uitgebreide bespreking van die Kaapse Patriottebeweging en konkludeer onder meer uit die versoek vir vrye verkiesings vir "burgerlijke Collegien" dat die beginsels van die demokrasie onder die Kaapse burgers wortel geskiet het. ${ }^{33} \mathrm{Hy}$ is verder van mening dat die politieke idees wat met die Franse Rewolusie wye bekendheid verkry het 'n beperkte invloed gehad op die leiers van die opstande wat teen die einde van die agtiende eeu in Graaaff-Reinet en Swellendam uitgebreek het, maar dat hulle ook beïnvloed is deur hul kennis van die stryd wat hul Nederlandse voorouers in die sestiende en vroeë sewentiende eeue teen die oorheersing van Spanje gevoer het. ${ }^{34}$

Volgens Scholtz het baie mense in Wes-Europa, onder die invloed van die Franse Rewolusie en die beskouinge van Rousseau oor die "edele barbaar", die inheemse bewoners van Afrika en ander wêrelddele in ' $n$ nuwe lig gesien, en dit het bygedra tot ' $n$ strewe om sendingwerk onder hulle te doen. Dit het ook die Britse owerheid, wat van 1795 tot 1803 die Kaapkolonie bestuur het, se beleid en optrede teenoor die swart mense op die oosgrens van die kolonie beïnvloed. Die veranderde beskouinge oor swart mense het egter nie die Afrikaners se sieninge in dié verband geraak nie. Onder invloed van sewentiende-eeuse en vroeg agtiendeeeuse Nederlandse opvattings het hulle swart mense beskou as afstammelinge van Gam wat diensbaar moet wees aan die blankes. Dit is ' $n$ opvatting wat volgens Scholtz baie nadelige gevolge vir die Afrikaners gehad het. ${ }^{35}$ Hierdie verskille in beskouinge het ook bygedra tot die konflik tussen die inwoners van Graaff-Reinet en die Britse owerheid gedurende die laat agtiende eeu. ${ }^{36}$

29 GD Scholtz, Die ontwikkeling..., band 1, p. 235.

30 GD Scholtz, Die ontwikkeling...,band 1, p. 251.

31 GD Scholtz, Die ontwikkeling..., band 1, p. 252.

32 GD Scholtz, Die ontwikkeling..., band 1, p. 261.

33 GD Scholtz, Die ontwikkeling...,band 1, p. 267.

34 GD Scholtz, Die ontwikkeling..., band 1, pp. 313-314.

35 GD Scholtz, Die ontwikkeling...,band 1, p. 217.

36 GD Scholtz, Die ontwikkeling...,band 1, p. 379. Scholtz verwerp dus die beskouing dat die swart mense diensbaar moet wees aan die blankes, maar, soos in latere bande van sy studie blyk, byvoorbeeld GD Scholtz, Die ontwikkeling..., band 8, p. 356, staan hy positief teenoor die beleid van die latere Nasionale Party, wat inhou dat daar "geen gelykstelling tusssen die rasse" en geen bloedvermenging tussen rasse moet plaasvind nie. 
Giliomee skryf, soos Scholtz, dat ' $\mathrm{n}$ groot mate van burgerlike vryheid gedurende die sewentiende eeu in Nederland geheers het en dat die Kaapse koloniste op dieselfde vryhede aanspraak gemaak het. ${ }^{37}$ Hulle het wel 'n oorwinning behaal in hul stryd teen WA van der Stel, maar hulle het, as onderdane van die Nederlands-Oos-Indiese Kompanjie, in werklikheid nie dieselfde regte as die burgers van die moederland gehad nie. ${ }^{38}$ Die Kaapse Patriotte van die laat agtiende eeu het verkeerdelik geglo dat die koloniste in die sewentiende eeu groter vryhede as hulle geniet het. ${ }^{39}$ Hoewel die Patriotte bekend was met die geskrifte van die Verligtingsdenkers, het hulle eintlik net van hulle uitsprake gebruik gemaak om besondere oogmerke van lokale belang te bereik. ${ }^{40}$ Die opstandelinge van Graaff-Reinet, wat feitlik ongeletterd was, het maar min verstaan van die politieke retoriek, geskoei op die idees van die Verligting, wat hul leiers gebruik het. ${ }^{41}$ Anders as Scholtz meen Giliomee dus dat die invloed van die Verligtingsdenkers en van die Amerikaanse en Franse Rewolusies op die beskouinge van die Kaapse koloniste maar baie beperk was. ${ }^{42}$

\section{Die Kaapkolonie, 1806-1910}

Volgens Scholtz het liberalisme in die negentiende-eeuse Kaapkolonie veral op twee gebiede na vore gekom: in beleidsmaatreëls rakende die verhoudinge tussen die verskillende bevolkingsgroepe, en in die strewe na selfbestuur onder die koloniste. In die eerste geval het liberalisme ' $n$ hoofsaaklik negatiewe invloed op die Afrikaner gehad en in die tweede geval ' $n$ oorwegend positiewe invloed. ${ }^{43}$ Scholtz toon aan dat die invloed van filantropiese aktiviste in Brittanje en in die kolonie gelei het tot die afskaffing van slawerny en tot maatreëls waarin vrygestelde slawe en inboorlinge gelyke regte met die koloniste verkry het. Wat die afskaffing van slawerny betref, wys hy daarop dat die Nederlandstalige koerant De Zuid-Afrikaan in 1832 geskryf het dat daar geen skepsel is "met reden begaafd en die een menselijk hart in zijnen boezem draagt, indien hij ten minste den invloed dezer Eeuw van verlichting gevoelt, of hij zal erkennen dat vrije arbeid veel wenselijker en op verre na verkieselijker is dan slaven arbeid". ${ }^{44}$ Scholtz erken dan ook dat die vrystelling van slawe "n "wenslike en noodsaaklike stap" was. ${ }^{45}$ Hy sien egter die opheffing van beperkings op die persoonlike vryheid van die Khoikhoi, soos veral beliggaam in die bekende Ordonnansie 50 van 1828, as 'n hoofsaaklik negatiewe ontwikkeling. ${ }^{46}$ Hy staan ook negatief teenoor die beleid van "konsiliasie" wat in die eerste dekades van die Britse bewind ten opsigte van die swart stamme aan die oosgrens

37 H Giliomee, The Afrikaners..., pp. 5-6.

38 H Giliomee, The Afrikaners..., p. 26.

39 H Giliomee, The Afrikaners..., p. 54.

$40 \quad$ H Giliomee, The Afrikaners..., p. 54.

41 H Giliomee, The Afrikaners..., p. 74.

42 Vergelyk A du Toit \& H Giliomee, Afrikaner political thought, 1780-1850; analysis and documents (Cape Town, David Philip, 1983), pp. 231-234, 238-242.

43 GD Scholtz, Die ontwikkeling..., band 2, p. 165.

44 GD Scholtz, Die ontwikkeling..., band 2, pp. 223-224.

45 GD Scholtz, Die ontwikkeling..., band 2, p. 225.

46 GD Scholtz, Die ontwikkeling...,band 2, p. 242-243. 
gevoer is en die integrasiebeleid van sir George Grey, goewerneur van die Kaapkolonie van 1854 tot $1861 .{ }^{47}$ Hierdie beleidsmaatreëls het volgens Scholtz die Nederlandse (of Afrikaanse) koloniste baie nadelig geraak. Hy is krities oor die rol van Andries Stockenström (1792-1864) wat, hoewel gedeeltelik van Sweedse afkoms, homself as deel van die Afrikaanse bevolkingsgroep beskou het. Stockenström het aanvanklik, as landdros van die distrik GraaffReinet, beleidsmaatreëls wat die veiligheid van die boere in die Oos-Kaap bedreig het, veroordeel, maar in 1835 voor ' $n$ kommissie van die Britse parlement verklaar dat die grensboere self gedeeltelik vir die probleme aan die oosgrens verantwoordelik was. Dit toon, volgens Scholtz, dat Stockenström in daardie jare weinig begrip vir die moeilikhede van die grensboere getoon het. ${ }^{48}$ Scholtz is verder van mening dat die verengelsingsproses in die Kaapkolonie daartoe gelei het dat sommige Afrikaners liberale denkbeelde oor verhoudinge tussen die bevolkingsgroepe gehuldig het en dat 'n koerant soos Het Volksblad hom uitgespreek het ten gunste van sosiale verhoudinge en huweliksvermenging tussen lede van die verskillende groepe as hulle op dieselfde beskawingsvlak is. ${ }^{49}$

Giliomee gaan veel dieper in op die hervormingsmaatreëls wat die Britse bewindhebbers in die jare na 1806 ten opsigte van die slawe en die inboorlinge ingestel het en ook op die rol van leiers onder die Afrikaanse gemeenskap in dié verband. Stockenström, WS van Rijneveld (1765-1812) en JA Truter (1763-1845), al drie Nederlandstalige koloniste wat amptenare in die Britse koloniale stelsel geword het, het geglo dat die Khoikhoi as vrye mense beskou moes word en dat ' $n$ stelsel waarin hulle persoonlike vryheid en reg op eiendom verseker is tot hul opheffing sou lei. Truter, wat gedurende sy loopbaan onder meer hoofregter en president van die Raad van Justisie was, het hom daarvoor beywer dat arbeidsverhoudinge in kontrakte vasgelê word. ${ }^{50}$ Van Rijneveld, Truter en Stockenström het ook hul medekoloniste probeer oortuig dat die maatskaplike stelsel hervorm moet word. ${ }^{51}$ Veral Stockenström het 'n belangrike rol gespeel in die hervorminge wat in die tydperk 1823 tot 1834 plaasgevind het en wat onder meer gelei het tot die afskaffing van slawerny. ${ }^{52}$ Stockenström, wat deur Giliomee beskryf word as die mees liberale Afrikaner van sy tyd, het geglo dat onderdrukking van inboorlinge eerder ' $n$ negatiewe as ' $n$ positiewe uitwerking op die koloniste se veiligheid gehad het. ${ }^{53}$ Giliomee toon aan dat Stockenström gekant was teen die kulturele assimilasie van die inboorlinge wat deur sommige liberale beleidsmakers voorgestaan is en later deur die maatreëls van Grey bevorder is. Stockenström het geglo dat daar nie gepoog moet word om die leefwyse van die Xhosagroepe te verander nie en dat verhoudinge met hierdie groepe deur verdrae met stamhoofde gereël moet word. ${ }^{54}$

47 GD Scholtz, Die ontwikkeling..., band 2, pp. 249-250, band 3, p. 218.

48 GD Scholtz, Die ontwikkeling..., band 2, pp. 250, 277.

49 GD Scholtz, Die ontwikkeling..., band 3, pp. 214-216.

50 H Giliomee, The Afrikaners..., p. 96.

51 H Giliomee, The Afrikaners..., pp. 95-96.

52 H Giliomee, The Afrikaners..., p. 102.

53 H Giliomee, The Afrikaners..., p. 104.

54 H Giliomee, The Afrikaners..., pp. 157-158; vergelyk A du Toit \& H Giliomee, Afrikaner political thought..., pp. 134-140. Die meeste liberale politieke denkers, vanaf John Philip in die vroeë negentiende eeu tot Edgar Brookes in die vroeë twintigste eeu, het gemeen dat 'n beleid van segregasie in die beste belang van die swart mense was. Vergelyk J Robertson, Liberalism in South Africa, 1948- 
Hoewel Scholtz die verlening van verteenwoordigende en later verantwoordelike bestuur aan die Kaapkolonie as ' $n$ positiewe ontwikkeling sien, staan hy tog krities teenoor William Porter, prokureur-generaal van die Kaapkolonie, wat ' $n$ kardinale rol gespeel het in die totstandkoming van die stelsel van verteenwoordigende bestuur in die Kaapkolonie. Hy haal 'n uitspraak van Porter aan dat selfbestuur tot ' $n$ samesmelting van ras, kleur en taal sal lei en dat daarmee vrede en voorspoed in die kolonie bereik sal word. ${ }^{55} \mathrm{Hy}$ bespreek kortliks die rol van Afrikaanse koloniste soos Christoffel Brand, Andries Stockenström en FW Reitz (senior) in die stryd om die verkryging van selfbestuur. Scholtz beskou die feit dat Engelstalige setlaars in die Oos-Kaap, dus "die Brit wat liberaalgesind was," hoë stemregkwalifikasies wou hê, wat baie Afrikaners en bruin mense sou uitsluit, terwyl Afrikaanse koloniste in die westelike distrikte, dit wil sê "die Afrikaner wat konserwatief gesind was", ten gunste was van laer kwalifikasies en geen "beginselbesware teen die kiesreg van die nie-blankes" gehad het nie, as "n paradoksale toestand wat nouliks sy weerga in die geskiedenis van Suid-Afrika het" ${ }^{56}$

Giliomee sien hierdie toestand nie as paradoksaal nie, maar noem die Britse setlaars van die Oos-Kaap wat hoë kwalifikasies wou hê die konserwatiewe groep teenoor die populêre party van die Wes-Kaap wat bestaan het uit Afrikaanse boere asook Engelse sakemanne en professionele mense. ${ }^{57}$ Hy haal uitsprake aan van Brand, Reitz en Stockenström waarin hulle hul ten gunste van stemreg vir bruin mense uitspreek. Daaruit blyk dit, volgens Giliomee, dat, ten minste, die elite onder die Kaapse Afrikaners teen 1850 die liberale vooruitgangsidee aanvaar het. Terwyl die politieke filosoof André du Toit argumenteer dat liberale politieke idees onder Afrikaners na 1853 gekwyn het, meen Giliomee dat hierdie idees tog voortbestaan het. ${ }^{58}$ Hy wys daarop dat die Afrikaner JH de Villiers (1842-1914), wat jare lank hoofregter van die Kaapkolonie (en later van die Unie van Suid-Afrika) was, 'n kardinale bydrae gelewer het om die idee dat elke mens, ongeag die kleur van sy vel, fundamente regte het in die Kaapse regstelsel te vestig. ${ }^{59}$

JW Sauer (1850-1913) was 'n belangrike Kaapse Afrikaanse politikus en minister in verskeie koloniale kabinette gedurende die jare 1881 tot 1910. Sauer, wat nooit lid was van die Afrikanerbond nie, word meesal, naas JX Merriman, WP Schreiner en andere, in geskiedwerke as een van die vernaamste verteenwoordigers van die sogenaamde Kaapse liberale tradisie bestempel. ${ }^{60}$ Scholtz verwys net kortliks na hom. Hy meld dat Sauer 'n "klap van die liberalisme weg gehad het" ${ }^{\prime 1}$ en dat hy ten gunste was van stemreg wat gebaseer is op

1963 (Oxford, Clarendon, 1971), p. 30; S Dubow, Racial segregation and the origins of apartheid in South Africa, 1919-1936 (Oxford, Macmillan, 1989), pp. 21-47.

55 GD Scholtz, Die ontwikkeling..., band 2, pp. 191-192.

56 GD Scholtz, Die ontwikkeling...,band 2, p. 198.

57 H Giliomee, The Afrikaners..., p. 119.

58 A du Toit, “The Cape Afrikaners' failed liberal movement, 1850-1870”, J Butler, R Elphick \& D Welsh (eds), Democratic liberalism in South Africa..., pp. 35-63; H Giliomee, The Afrikaners..., p. 121.

59 H Giliomee, The Afrikaners..., p. 121.

60 Vergelyk TRH Davenport, The Afrikaner Bond; the history of a South African political party, 1880-1911 (Cape Town, Oxford University Press, 1966), pp. 153, 185; P Lewsen, "The Cape liberal tradition: myth or reality?", Race, 13, 1, 1971, pp. 71-72. 
beskaafdheid en nie velkleur nie. ${ }^{62}$ Volgens Giliomee het Sauer sowel die potensiaal as die beperkinge van Kaapse liberalisme beliggaam. Hy het goeie verhoudinge met die swart mense van die Oos-Kaap gehandhaaf en kon hom nie vereenselwig nie met die beskouinge van sommige Kaapse politici dat, op grond van die feit dat reservate vir hulle opsy gesit is, daar in die ander dele van die kolonie teenoor hulle gediskrimineer mag word nie. Hy was tog nie ten gunste van integrasie tussen blank en swart nie en het die aparte ontwikkeling van swart mense voorgestaan. Hy het ook geglo dat as blankes hulle in die Transkei sou vestig, dit daartoe sou lei dat hulle tot 'n staat van barbarisme verval. Politieke regte, maar nie sosiale regte nie, moet tussen blank en swart gedeel word. ${ }^{63}$

Scholtz is van mening dat die leier van die Afrikanerbond, JH Hofmeyr (1845-1909), ook bekend as Onze Jan, soos Sauer "'n klap van die liberalisme weg gehad" het. ${ }^{64}$ Hy toon aan dat Hofmeyr politieke samewerking tussen blankes en bruin mense voorgestaan het. Hofmeyr het in koerantartikels daarop gewys dat bruin mense dieselfde taal as die Afrikaners praat en dat dit in albei groepe se belang is dat Nederlands op skool en in die geregshowe gelyke behandeling met Engels geniet. As die Afrikaners nie die bruin mense hul bondgenote maak nie, word hulle, so meen Hofmeyr, in die hande van die Engelssprekende koloniste gedryf. ${ }^{65}$ Hoewel Hofmeyr, volgens Scholtz, ook toelating van bruin mense tot die Afrikanerbond voorgestaan het, het dit nooit gebeur nie. ${ }^{66}$ Scholtz meen dat, omdat die Afrikanerbond nie gelykheid op sosiale vlak met die bruin mense bevorder het nie, terwyl "aanhangers van die liberalisme" bereid was om wel sosiaal met hulle om te gaan, min bruin mense vir Afrikaanse kandidate in verkiesings gestem het. ${ }^{67}$ Giliomee sien net sekere elemente van 'n liberale politieke uitkyk by Hofmeyr en die Afrikanerbond. Die Afrikanerbond het bepaalde liberale waardes gehuldig, soos skeiding tussen kerk en staat, persvryheid en 'n onafhanklike regbank, maar hulle was gekant teen groter politieke regte vir swart mense, veral omdat hulle gemeen het dat dit ekonomiese stabiliteit en ontwikkeling sou bedreig. Die Afrikanerbond het kultuur en beskawing eerder as ras as kriterium vir stemreg voorgestaan, maar uit Hofmeyr se uitsprake blyk dit dat hy soms beskawing en ras met mekaar gelykgestel het. ${ }^{68}$

\section{Die Boererepublieke}

Volgens Scholtz toon die demokratiese bestuurstelsel wat die Voortrekkers in 1836 in die lewe geroep het die invloed van die beskouinge van die Kaapse Patriotte. ${ }^{69}$ Verder was die grondwet van die Vrystaatse Republiek geskoei op die konstitusie van die VSA en dié van die

62 GD Scholtz, Die ontwikkeling..., band 5, p. 376.

63 H Giliomee, The Afrikaners..., pp. 285, 287, 302-303.

64 GD Scholtz. "Liberalisme in die perswese", PS Dreyer (red.), Afrikaner-liberalisme, p. 54.

65 GD Scholtz, Die ontwikkeling..., band 4, pp 171-172.

66 GD Scholtz, Die ontwikkeling...,band 4, pp. 300-301; vergelyk TRH Davenport, The Afrikaner Bond..., p. 119.

67 GD Scholtz, Die ontwikkeling...,band 4, p. 172.

68 H Giliomee, The Afrikaners..., pp. 289-290.

69 GD Scholtz, Die ontwikkeling...,band 2, p. 591. 
Zuid-Afrikaansche Republiek (ZAR) op die grondwet van die Bataafse Republiek, wat van 1795 tot 1806 in Nederland bestaan het. ${ }^{70}$ In die Boerepublieke het daarom ' $n$ ander vorm van demokrasie gegeld as in die Kaapkolonie en Natal, waar dit, volgens Scholtz, 'n tipies Britse inslag gehad het. ${ }^{71}$ Soos in die vorige afdeling aangedui, meen Giliomee dat die politieke idees wat deur die Amerikaanse en Franse Rewolusies uitgedra is maar 'n baie oppervlakkige invloed in die Kaapkolonie, en veral in die Oos-Kaap, gehad het. Tog skryf hy dat kernidees van die Amerikaanse en Franse republieke, waaronder ' $n$ vry, onafhanklike klas van burgers wat eiendom besit en bepaalde regte, pligte en voorregte het, by die Voortrekkers ingang gevind het. ${ }^{72} \mathrm{Hy}$ wys daarop dat ras in die Vrystaatse grondwet nie so eksplisiet as 'n uitsluitingsmeganisme vir stemreg as in die Transvaalse konsitusie gebruik is nie ${ }^{73}$ en dat in beide republieke regeringsleiers en burgers respek vir demokratiese beginsels soos 'n onafhanklike regbank gehad het. ${ }^{74}$ Scholtz en Giliomee meen dus albei dat liberale politieke beskouinge van die Verligtingstydperk ' $n$ invloed op die regeringstelsel en regeringspraktyke van die Voortrekkers en republikeinse Boere gehad het.

Van die regeringshoofde in die twee republieke het slegs TF Burgers volgens Scholtz liberale beskouinge gehad, wat veral uit sy teologiese liberalisme voortgespruit het. Dit het daartoe gelei dat hy gekant was teen godsdiensonderrig op skole en van Nederlandse amptenare met liberale of "vrysinnnige" beskouinge gebruik gemaak het. ${ }^{75}$ Hy gee toe dat Paul Kruger, toe hy later president van die ZAR geword het, ook Nederlanders met "vrysinnige" godsdienstige oortuigings, by name WJ Leyds, aangestel het. ${ }^{76}$ Daar was in die tyd van Kruger ' $\mathrm{n}$ "progressiewe" groep in die Volksraad met generaal Piet Joubert as leier, teenoor die "konserwatiewe" groep wat Kruger se beleid gesteun het, maar in werklikheid was daar volgens Scholtz weinig sprake van beginselverskille tussen die twee leiers. ${ }^{77}$ Hy meen dan ook dat die liberalisme nooit werklik ingang in die Boererepublieke gevind het nie. ${ }^{78}$

Giliomee bestempel Burgers as ' $n$ idealis wat uit voeling was met die konserwatiewe sentimente van die Transvaalse burgers. ${ }^{79} \mathrm{Hy}$ verwys net kortliks na die "progressiewe" groep onder die Transvalers in die laaste twee dekades van die ZAR se bestaan, wat, volgens hom, vinniger modernisering van die republek voorgestaan het as wat onder Kruger se regering plaasgevind het. ${ }^{80}$ Hy sien, net so min as Scholtz, belangrike ontwikkelinge op die gebied van liberale politieke denke in die Boererepublieke.

70 GD Scholtz, Die ontwikkeling..., band 3, pp. 171, 187.

71 GD Scholtz, Die ontwikkeling...,band 3, p. 197.

72 H Giliomee, The Afrikaners..., p. 167.

73 H Giliomee, The Afrikaners..., p. 176.

74 H Giliomee, The Afrikaners..., pp. 235, 244.

75 GD Scholtz, Die ontwikkeling...,band 3, pp. 499, 501.

76 GD Scholtz, Die ontwikkeling...,band 4, p. 342.

77 GD Scholtz, Die ontwikkeling...,band 4, pp. 338-339.

78 GD Scholtz. "Liberalisme in die perswese", PS Dreyer (red.), Afrikaner-liberalisme, p. 54.

79 H Giliomee, The Afrikaners..., pp. 187-188.

$80 \quad$ H Giliomee, The Afrikaners..., p. 238. 


\section{Die tydperk 1910-1948}

Scholtz toon aan dat die Afrikanerbond, onder leiding van FS Malan (1871-1941), en die Suid-Afrikaanse Party, waarin die Afrikanerbond opgegaan het, ten gunste van gelyke politieke regte vir blankes, bruin en swart mense was. ${ }^{81}$ By die Nasionale Konvensie wat uniewording in 1910 voorafgegaan het, het Malan dan ook gepleit vir uitbreiding van swart stemreg oor die hele Suid-Afrika. ${ }^{82}$ Nogtans meen Scholtz dat die kompromis oor stemreg (naamlik behoud van gekwalifiseerde stemreg in die Kaapkolonie en van uitsluitlik blanke stemreg in die Oranje-Vrystaat en Transvaal), wat in die grondwet van 1910 opgeneem is, gesien moet word as 'n kompromis tussen "die Afrikaanse lewensbeskouing en die Britse liberalisme". ${ }^{83}$ Oor Malan maak hy verder net enkele opmerkings. Daarenteen skenk Scholtz, veral in die laaste twee bande van sy werk, baie aandag aan die politieke denke van JH Hofmeyr (1894-1948), wie se vader 'n neef was van Onze Jan. Scholtz meen dat Hofmeyr, al was hy "een van die begaafdste manne wat die Afrikaanse volk nog voortgebring het", ${ }^{4}$ na sy studiejare aan ' $n$ Britse universiteit, net soos JC Smuts, geestelik nie meer 'n Afrikaner was nie. ${ }^{85}$ Hofmeyr se toetrede tot die partypolitiek in 1929 het "n "verlewendiging" van die liberalisme gebring. ${ }^{86}$ Scholtz maak gebruik van koerantartikels en ook van Paton se biografie ${ }^{87}$ om Hofmeyr se uitsprake oor sowat twee dekades onder die loep te neem. Hy dui onder andere aan dat Hofmeyr, soos ander liberale denkers in daardie jare, wegbeweeg het van die idee van segregasie en aparte ontwikkeling en eerder 'n gemeenskaplike samelewing van blankes en swart mense vir Suid-Afrika voorgestaan het. ${ }^{88}$ Scholtz meen dat in die verslag van die Fagankommissie van 1948 oor die posisie van die swart mense in die land Hofmeyr sowel as Smuts se standpunte na vore kom. ${ }^{89} \mathrm{Hy}$ sien Hofmeyr as die siel van die liberale beweging van die 1930's en 1940's. Sy oorlye in 1948 het die liberalisme 'n slag toegedien waarvan "dit nooit weer kon herstel nie". ${ }^{90}$

Scholtz beskou Smuts nie as ' $n$ liberale politikus nie en tipeer sy politieke filosofie eerder as "holistiese imperialisme". ${ }^{91} \mathrm{Hy}$ haal verskeie van Smuts se uitsprake aan waaruit blyk dat hy, wat betref die beleid oor die verhouding tussen die bevolkingsgroepe, eerder as 'n pragmatis gesien moet word. ${ }^{92}$ Smuts het byvoorbeeld in 1936 verklaar dat hy nie ten alle koste die behoud van gekwalifiseerde stemreg in die Kaapprovinsie steun nie. As dit van die swart mense weggeneem word, moet dit wees vir baie ernstige redes en daar moet dan iets in die

81 GD Scholtz, Die ontwikkeling..., band 5, p. 454, band 6, p. 463.

82 FA Mouton, Prophet without honour..., p. 89.

83 GD Scholtz, Die ontwikkeling..., band 5, p. 557.

84 GD Scholtz, Die ontwikkeling...,band 7, p. 112.

85 GD Scholtz, Die ontwikkeling...,band 7, p. 105.

86 GD Scholtz, Die ontwikkeling..., band 7, p. 114.

87 A Paton, Hofmeyr.

88 GD Scholtz, Die ontwikkeling..., band 7, p. 490.

89 GD Scholtz, Die ontwikkeling..., band 8, p. 495.

90 GD Scholtz, Die ontwikkeling..., band 8, p. 348.

91 GD Scholtz, Die ontwikkeling..., band 7, p. 105.

92 Vergelyk S Dubow, Racial segregation..., pp. 141-142. 
plek daarvan gestel word. Daarom kon hy hom (anders as Hofmeyr) met die plasing van swart mense op 'n aparte kieserslys versoen..$^{93}$

Giliomee beskryf FS Malan as ' $n$ leidende Kaapse liberaal in die eerste Smutskabinet wat maatreëls deurgevoer het om die posisie van swart werkers te verbeter en wat nog in 1936, anders as die leiers van die Verenigde Party, waarvan hy toe lid was, die uitbreiding van die Kaapse gekwalifiseerde stemreg na die ander provinsies bepleit het. ${ }^{94}$ Giliomee sien, soos Scholtz, Hofmeyr (junior) as die vernaamste liberale leier in die parlement gedurende die dertiger- en veertigerjare, ${ }^{95}$ maar gee veel minder aandag aan sy beskouinge. Dit blyk dat hy hom, anders as Scholtz, nie as dié sentrale figuur in die ontwikkeling van liberale politieke denke beskou nie. Giliomee bestempel Smuts as die verpersoonliking van blanke SuidAfrikaanse dubbelsinnigheid oor die rassevraagstuk. ${ }^{96}$ In 1928 was hy ten gunste van uitbreiding van gekwalifiseerde stemreg, soos in die Kaapprovinsie, na die res van die land, maar in 1936 het hy die segregasiewetgewing van die destydse eerste minister, JBM Hertzog, al is dit teensinnig, aanvaar. ${ }^{97}$

\section{Die periode 1948-1975}

In sy biografie van Hendrik Verwoerd ${ }^{98}$ en in ander geskrifte waarin hy oor die periode na 1948 handel, ${ }^{99}$ verwys Scholtz hoofsaaklik na die liberalisme as 'n ideologie wat die Afrikaner van buite bedreig. Die aanhangers daarvan in Suid-Afrika was veral die Liberale Party, met Alan Paton as belangrikste leiersfiguur, en die Progressiewe Party, met Helen Suzman as vernaamste spreekbuis, ${ }^{100}$ asook enkele prominente Rooms-Katolieke en Anglikaanse geestelikes en "ontstamde Bantoeleiers". ${ }^{101}$ Engelstalige universiteite sien hy as belangrike sentra van liberale politieke denke. ${ }^{102} \mathrm{Hy}$ haal met instemming Verwoerd se afwysende uitsprake aan oor Afrikaanse skrywers, koerantredakteurs en teoloë wat gepleit het vir die opheffing van sommige apartheidsmaatreëls. ${ }^{103}$ In 1977 verklaar Scholtz dat sekere Afrikaanse koerante "gedagtes uitspreek wat duidelik aan die arsenaal van die liberalisme ontleen is". ${ }^{104}$ Hierdie koerante (waarvan hy net Die Transvaler by name noem) gebruik die term verligtheid

93 GD Scholtz, Die ontwikkeling..., band 7, p. 523.

94 Giliomee, The Afrikaners..., pp.243, 313, 414.

95 Giliomee, The Afrikaners..., pp. 413, 447.

96 Giliomee, The Afrikaners..., p. 304

97 Giliomee, The Afrikaners..., pp. 339, 413.

98 GD Scholtz, Dr Hendrik Frensch Verwoerd, 1901-1966 (Johannesburg, Perskor, 1974, 2 bande).

99 Veral van belang is: GD Scholtz, Die bedreiging van die liberalisme (Johannesburg, Voortrekkerpers, 1965); GD Scholtz, "Liberalisme in die perswese", PS Dreyer (red.), Afrikaner-liberalisme, pp 53-70.

100 GD Scholtz, Die bedreiging van die liberalisme, pp. 60-68.

101 GD Scholtz, Die bedreiging van die liberalisme, p. 66; GD Scholtz, Dr Hendrik Frensch Verwoerd, 19011966, band 1, p. 295, band 2, p. 136.

102 GD Scholtz, Dr Hendrik Frensch Verwoerd, 1901-1966, band 2, p. 141.

103 GD Scholtz, Dr Hendrik Frensch Verwoerd, 1901-1966, band 2, pp. 168-170.

104 GD Scholtz, "Liberalisme in die perswese", PS Dreyer (red.), Afrikaner-liberalisme, p.53. 
eerder as liberalisme, maar het, volgens Scholtz, die pad van DF Malan en HF Verwoerd verlaat en volg nou die pad van Hofmeyr. Hofmeyr het onder meer verklaar dat die aanwesigheid van swart mense in "blanke gebiede" as permanent aanvaar moet word en was gekant teen wetgewing om "gemengde" huwelike te verbied, en hierdie beskouinge word nou deur sommige Afrikaanse koerantredakteurs en teoloë gehuldig. ${ }^{105}$ Scholtz verwyt dit die verligte redakteurs en teoloë dat hulle nog steeds voorgee om Afrikanernasionaliste te wees. Hy vra hulle om "die vlag van die Afrikaanse nasionalisme" te laat sak en onder die vlag van "die liberalisme van die Hofmeyrskool" te vaar. ${ }^{106}$

Giliomee skryf dat Phil Weber, redakteur van Die Burger, in 1953 leiers van die Nasionale Party probeer oorreed het om bruin mense nie van die gemeenskaplike kieserslys te verwyder nie en eerder hoë stemregvereistes vir nuwe bruin kiesers in te stel. Onder leiding van die Transvaler JG Strijdom was die party egter nie daarvoor te vinde nie en is voortgegaan om bruin mense van die gemeenskaplike lys verwyder te kry. ${ }^{107}$ Schalk Pienaar, redakteur van Die Beeld, het reeds in die sestigerjare verklaar dat die permanentheid van swart mense in die gebiede buite die tuislande aanvaar moet word. ${ }^{108}$ Pienaar en ander verligtes het slegs geleidelike hervorming bepleit en wou blanke beheer in Suid-Afrika behou. Hulle kan daarom moeilik as liberale denkers bestempel word. ${ }^{109}$ Giliomee se beskouing oor die verligtes in die Nasionale Party verskil dus sterk van dié van Scholtz.

Giliomee toon verder aan dat HA Fagan (1889-1963) een van slegs enkele Afrikaanse politici was wat in die vyftigerjare 'n alternatief vir die apartheidsbeleid aangedui het. Fagan, wat 'n minister in die laaste Hertzogkabinet was en later hoofregter geword het, het geglo dat gemeenskaplike waardes en 'n gevoel van eenheid tussen blankes en swart mense noodsaaklik is vir die uitbreiding van stemreg na swart mense. Aanvanklik sou dus slegs die swart middelklas stemreg kan verkry. ${ }^{110}$ Liberale beskouinge het volgens Giliomee in die jare na 1948 verder veral by Afrikaanse skrywers en akademici na vore gekom. NP van Wyk Louw (1906-1970), een van die belangrikste digters wat Suid-Afrika opgelewer het, het hom uitgespreek ten gunste van liberale nasionalisme, waarmee hy bedoel het dat 'n vorm van apartheid wat nie in botsing was nie met die liberale nasionalisme wat in Westerse lande voorgekom het gevind moes word. Louw het Hofmeyr se beskouinge oor die uitbreiding van stemreg verwerp en liberale politieke denkers gevra om 'n beleid voor te stel wat vryheid en gelyke geleenthede vir almal verseker sonder dat die Afrikaners ' $n$ magtelose minderheid in die land word. ${ }^{111} \mathrm{Hy}$ het geglo dat die bruin mense "ons mense" is, wat dus as Afrikaners beskou moet word, ${ }^{112}$ en ook Afrikaners daarteen gewaarsku dat hulle op ' $n$ krisis afstuur as

105 GD Scholtz, “Liberalisme in die perswese”, PS Dreyer (red.), Afrikaner-liberalisme, pp. 57, 62, 67, 68.

106 GD Scholtz, "Liberalisme in die perswese", PS Dreyer (red.), Afrikaner-liberalisme, p. 70.

107 H Giliomee, The Afrikaners..., p. 501.

108 H Giliomee, The Afrikaners..., p. 535.

109 H Giliomee, The Afrikaners..., p. 549; vergelyk H Giliomee, “Apartheid, Verligtheid and liberalism”, J Butler, R Elphick \& D Welsh (eds), Democratic liberalism.., p. 369.

110 H Giliomee, “'Survival in justice': an Afrikaner debate over apartheid”, Comparative Studies in Society and History, 36, 1994, p. 534; H Giliomee, The Afrikaners..., p. 498.

111 H Giliomee, “Apartheid, Verligtheid and liberalism”, J Butler, R Elphick \& D Welsh (eds), Democratic liberalism..., pp. 367-368; H Giliomee, The Afrikaners..., p. 472.

112 H Giliomee, The Afrikaners..., p. 526. 
dit vir hulle gaan om voortbestaan ten alle koste eerder as om voortbestaan in geregtigheid. ${ }^{113}$ Ander skrywers, onder meer Dirk Opperman, Jan Rabie en André Brink, het in hul werke en in openbare uitsprake die apartheidsbeleid gekritiseer. Nie een van hulle het, soos Louw, hul politieke beskouinge sistematies uiteengesit nie, maar tog 'n belangrike bydrae gelewer om die politieke uitkyk van die Afrikaners te verander. ${ }^{114}$ Hierbenewens het akademici soos Ben Marais, Bennie Keet, LJ du Plessis, Nic Olivier en Johannes Degenaar skerp kritiek op die apartheidsbeleid uitgespreek. ${ }^{115}$ Giliomee verwys na Frederik van Zyl Slabbert as een van die belangrikste liberale politieke denkers wat in die sewentigerjare uit Afrikanergeledere voortgekom het. Hy het egter eers in 1979, toe hy as leier van die Progressiewe Federale Party aangewys is, 'n invloedryke figuur in die Suid-Afrikaanse politiek geword. ${ }^{116}$

\section{Slotbeskouing}

Dit blyk uit Scholtz en Giliomee se studies dat nog baie meer navorsing oor Afrikaanse liberale politieke denke vanaf die agtiende eeu en die invloed daarvan gedoen kan word en dat daar ruimte is vir nuwe interpretasies ten opsigte van belangrike aspekte van die ontwikkeling van die Afrikaanse politieke denke. Beyers se studie van die Kaapse Patriottebeweging is byvoorbeeld reeds meer as tagtig jaar gelede onderneem ${ }^{117}$ en 'n nuwe omvattende geskiedwerk oor hierdie beweging mag groter duidelikheid gee oor die aard en omvang van die invloed wat die politieke idees van die Verligting op die Kaapse koloniste gehad het. Daar is nog geen uitgebreide biografiese studies van figure soos Truter, Stockenström en Sauer gedoen nie, en meer navorsing oor Afrikaanse politieke leiers van die negentiende behoort tot groter insig oor hul plek binne die Kaapse liberale tradisie te lei. Dit lyk waarskynlik dat daar onder toekomstige historici heelwat belangstelling sal wees in die rol en invloed van liberale Afrikaanse politici en politieke denkers in die twintigste eeu, in besonder gedurende die apartheidsperiode. Giliomee het baanbrekerswerk in hierdie verband gelewer, maar daar is ruimte vir heelwat meer navorsing oor hierdie onderwerp.

Scholtz het die omvattendste studie wat tans bestaan oor die ontwikkeling van die Afrikaanse politieke denke geskryf, maar sy beskouing dat liberalisme vreemd is aan die Afrikaner lei ongelukkig tot ' $\mathrm{n}$ eensydige en selfs verdraaide interpretasie van liberale denke onder Afrikaners. Dit doen afbreuk aan die waarde van sy werk. Die siening dat Afrikaners wat liberale beskouinge huldig dit doen as gevolg van die invloed van Engelssprekende SuidAfrikaners of van ' $n$ verblyf in Brittanje, is egter nie net eie aan sy interpretasie nie, maar kom ook onder verskeie Afrikaanse én Engelstalige wetenskaplikes van sy generasie voor. In die 1930's en1940's het sommige Afrikaanse denkers en politici die "liberale demokrasie", soos

113 H Giliomee, “'Survival in justice'...”, Comparative Studies in Society and History, 36, 1994, p 532; H Giliomee, The Afrikaners, p. 473.

114 H Giliomee, The Afrikaners..., pp. 524, 554.

115 H Giliomee, The Afrikaners..., pp. 484, 485, 523, 529, 555; vergelyk H Giliomee, " 'Survival in justice'...", Comparative Studies in Society and History, 36, 1994, pp 527-548; H Giliomee, "Critical Afrikaner intellectuals and apartheid, 1943-1958”, South African Journal of Philosophy, 19, 4, 2000, pp. 321-339.

116 Vergelyk H Giliomee, The Afrikaners..., p. 610.

117 'n Hersiene uitgawe, C Beyers, Die Kaapse Patriotte, het in 1967 verskyn, maar bevat min veranderings aan die oorspronklike teks, wat in 1929 gepubliseer is. 
dit toe in Suid-Afrika bestaan het, as van Britse oorsprong beskou en het geglo dat ' $n$ outoritêre politieke stelsel, soos in Nazi-Duitsland en Fascistiese Italië, meer geskik sou wees om Afrikaners se politieke strewe uit te te leef. ${ }^{118}$ Die feit dat Scholtz hom tog uitspreek teen ' $n$ outoritêre politieke stelsel en ten gunste van die demokrasie ${ }^{119}$ hang daarmee saam dat hy liberalisme en demokrasie van mekaar probeer losmaak, soos hierbo aangetoon is.

Verskeie Engelstalige akademici het eweneens liberalisme beskou as iets wat spesifiek met Britse politieke idees verbind moet word. WM Macmillan en EA Walker, wat gewoonlik as behorende tot die liberale skool van historici beskou word, ${ }^{120}$ skryf byvoorbeeld dat die Voortrekkers gevlug het van die beskawing en vooruitgang wat die Britse bestuur vanaf 1806 na die Kaap gebring het. ${ }^{121}$ Met uniewording in 1910 is die konserwatiewe Afrikaanse politieke beskouinge in die grondwet opgeneem en dit het uiteindelik tot die beleid van apartheid gelei. ${ }^{122}$ Hierdie siening is tans grotendeels gediskrediteer deur historici soos Timothy Keegan en Paul Maylam, wat daarop wys dat die Britse koloniale beleid beslis nie sonder meer as liberaal getipeer kan word nie en dat sowel Afrikaanse as Britse koloniste verdrukkende rassepraktyke voorgestaan het. ${ }^{123}$ Soos Scholtz en Giliomee albei aantoon, was dit juis die Engelstalige koloniste van die Oos-Kaap wat in die middel van die negentiende eeu hoë stemregkwalifikasies, wat feitlik alle bruin en swart mense sou uitsluit, voorgestaan het. Verder het, soos algemeen bekend, politieke partye met 'n liberale politieke program voor 1975 maar min steun onder Afrikaanse én Engelstalige kiesers ontvang.

Dit blyk uit die werk van Giliomee dat dit onjuis is om liberale politieke beskouinge direk met Groot-Brittanje en Engelstalige blankes en konserwatiewe politieke beskouinge met die Afrikaners te verbind. Soos hierbo aangetoon, kan Groot-Brittanje wel as die bakermat van liberale idees beskou word, maar hierdie idees het vanaf die agtiende eeu oor baie dele van die Westerse wêreld versprei en reeds ' $n$ invloed op die Kaapse koloniste gehad in die Nederlandse bestuurstydperk. Soos verskeie skrywers aandui, was Brittanje die vernaamste bron van negentiende-eeuse liberale beskouinge aan die Kaap en hierdie beskouinge is aanvanklik veral deur Britse sendelinge in die Kaapkolonie verkondig. ${ }^{124}$ Die Afrikaners is deur die opvattinge van sendelinge soos John Philip en koloniste soos John Fairbairn beïnvloed, maar liberale beskouinge onder Afrikaners kan nie sonder meer as ' $\mathrm{n}$ gevolg van die verengelsingsproses in die Kaapkolonie gesien word nie. Reeds in die laaste jare van die

118 Vergelyk TD Moodie, The rise of Afrikanerdom; power, apartheid and the Afrikaner civil religion (Berkeley, University of California Press, 1975), pp. 208-233.

119 GD Scholtz, Die ontwikkeling... band 8, pp. 105-112.

120 FA van Jaarsveld, Omstrede Suid-Afrikaanse verlede..., pp. 33-52; K Smith, The changing past..., pp. 103-131.

121 WM Macmillan, Bantu, Boer and Briton; the making of the South African native problem (Oxford, Clarendon, 1963, revised edition), p. 195; EA Walker, The Great Trek (London, Adam \& Charles Black, 1985, revised edition), p. 374.

122 Vergelyk FA van Jaarsveld, Omstrede Suid-Afrikaanse verlede..., p. 56.

123 T Keegan, Colonial South Africa and the origins of the racial order (Cape Town, David Philip, 1996), pp. 7-8; P Maylam, South Africa's racial past; the history and historiography of racism, segregation and apartheid (Aldershot, Ashgate, 2001), pp. 93-99.

124 P Lewsen, “The Cape liberal tradition...” Race, 13, 1, 1971, p. 70; R Davenport, “The Cape liberal tradition to 1910", J Butler, R Elphick \& D Welsh (eds), Democratic liberalism..., p. 30; FA Mouton, Prophet without honour..., p. 88. 
Kompanjiesbewind en ook in die tydperk 1803-1806, toe die Kaapkolonie onder beheer was van die Bataafse Republiek, het denkbeelde van die Verligting by ten minste ' $n$ deel van die koloniste ingang gevind. Giliomee toon aan dat Nederlandstalige koloniste soos Van Rijneveld en Truter reeds vroeg in die negentiende eeu, dus nog voor Philip en Fairbairn invloedryk geword het, groter persoonlike vryhede vir die Khoikhoi voorgestaan het.

Dit blyk uit bostaande afdeling oor die Boererepublieke dat daar in hierdie state, anders as in die Kaapkolonie, weinig sprake was van liberale denke onder politieke leiersfigure. Dit kan moeilik slegs aan ' $n$ gebrek aan Britse of Engelse invloed toegeskryf word, veral aangesien daar ook in koloniale Natal geen belangrike liberale politieke denkers was nie. ${ }^{125}$ Soos vroeër aangedui, het aanhangers van die liberalisme, vanaf die sewentiende eeu tot tans, hoofsaaklik onder die stedelike middelklas voorgekom. In die Kaapkolonie was daar veel meer geskoolde mense wat die professies beoefen het of sake-ondernemings bedryf het as in die Boererepublieke of Natal.

Stanley Trapido, wat gereken kan word tot die radikale of materialistiese skool van geskiedskrywers oor Suid-Afrika, ${ }^{126}$ skryf dat die liberalisme, soos dit in die negentiende eeu in Brittanje en in die Kaapkolonie toegepas is ' $n$ ideologie van beheer was, wat beteken dat diegene wat in beheer van die staat is geleidelik meer mense by die politieke stelsel betrek veral om hul eie ekonomiese belange te beskerm. ${ }^{127}$ Sonder twyfel wou liberale politieke leiers in die Suid-Afrikaanse verlede, soos enige ander politieke leiers, hul eie belange bevorder. Dit beteken egter nie dat persone soos Andries Stockenström, Saul Solomon en JH de Villiers nie sterk oortuiginge ten opsigte van basiese menseregte en vryhede gehad het nie. ${ }^{128}$ Trapido se stelling maak dit verder duidelik dat dit in die twintigste eeu moeiliker geword het om liberale beskouinge te huldig omdat die moontlikheid groter geword het dat swart mense die meerderheid van die kiesers sou vorm en 'n einde maak aan beheer deur blankes, of in elk geval deur mense wat in alle opsigte die Westerse kultuur, en veral die Westerse politieke kultuur, hul eie gemaak het. Ook blyk hieruit dat geskiedskrywers wat die apartheidsbeleid uit inherent konserwatiewe (of onliberale) beskouinge van Afrikaners probeer verklaar, die besondere omstandighede waarin hulle as minderheidsgroep in Suid-Afrika verkeer het as kernfaktor uit die oog verloor.

'n Groot deel van die liberale politieke leiersfigure in die Suid-Afrikaanse geskiedenis kan as deel van die Engelssprekende blanke gemeenskap geklassifiseer word. Daar was onder meer John Philip, John Fairbairn, William Porter, Saul Solomon, JX Merriman, WP Schreiner, Olive Schreiner, James Rose Innes, Alan Paton en Helen Suzman. Daar was egter ook belangrike figure met ' $n$ Afrikaanse agtergrond: JA Truter, Andries Stockenström, JH de

125 In Natal is verantwoordelike bestuur eers in 1893 ingestel. Die vernaamste politieke leiers in hierdie tydperk, H Escombe en J Robinson, het wel in bepaalde opsigte liberale beskouinge gehuldig, maar was, soos die meeste blanke koloniste, gekant teen politieke regte vir die Indiërbevolking van die kolonie. Vergelyk EH Brookes \& C de B Webb, A history of Natal (Pietermaritzburg, University of Natal Press, 1987, revised edition), veral pp. 172-173.

126 Vergelyk K Smith, The changing past...,p. 164..

127 S Trapido, “'The friends of the natives': merchants,peasants and the political and ideological structure of liberalism at the Cape, 1854-1910", S Marks \& A Atmore, Economy and society in pre-industrial South Africa (London, Longman, 1980), pp. 248-249.

128 Vergelyk R Davenport, “The Cape liberal tradition to 1910”, J Butler, R Elphick \& D Welsh (eds), Democratic liberalism..., veral p. 34. 
Villiers, JW Sauer, FS Malan en JH Hofmeyr (junior). Hierdie persone kan nie net as enkele geïsoleerde gevalle beskou word nie. Daar is ' $n$ belangrike mate van kontinuiteit te vinde in die ontwikkeling van liberale politieke denke onder Afrikaners: van die Kaapse Patriotte tot by vroeg negentiende-eeuse koloniste soos Truter en Stockenström; daarvandaan na De Villiers en Sauer in die tweede helfte van die eeu; dan na Malan en Hofmeyr in die periode voor 1948; en uiteindelik na liberale denkers in die apartheidstyd. Hoewel nie een van hierdie figure as ' $n$ belangrike politieke leier onder die Afrikaners beskou kan word nie, vorm hulle beskouinge en optrede tog, soos Giliomee aantoon, onlosmaaklik deel van die politieke en intellektuele geskiedenis van die Afrikaners. Soos dit veral uit die loopbaan van Malan blyk, ${ }^{129}$ was dit moontlik om liberale opvattinge te huldig en ook ' $n$ kampvegter vir die Afrikaanse taal en kultuur te wees. Eers in die jare na 1948 het liberale politieke idees en nasionalistiese Afrikaanse strewes direk met mekaar in botsing gekom. Ten einde beheer oor die land te behou, wat vir die meeste Afrikaners onlosmaaklik verbind was met die voortbestaan van die volk, is ' $\mathrm{n}$ stelsel tot stand gebring wat feitlik die teenoorgestelde van 'n liberale politieke bedeling was. In die apartheidsperiode het dit moeilik geword om 'n lojale Afrikaner te bly en ook liberale idees te aanvaar, soos onder andere blyk uit die pogings van Van Wyk Louw om nasionalisme met liberale waardes te versoen. ${ }^{130}$

Dit is eintlik eers in die tydperk na 1975 dat dit vir baie Afrikaanse politici en intellektuele duidelik geword het dat blanke oppergesag in Suid-Afrika nie meer lank sou kon voortduur nie en dat die beste waarborg vir hul politieke regte in 'n grondwet lê waarin liberale waardes verskans is. FW de Klerk, die laaste persoon wat aan die hoof gestaan het van 'n regering wat gedomineer is deur die Nasionale Party, het daarom in die jare na 1990 as die belangrikste Afrikaanse kampvegter vir liberale politieke beginsels na vore getree. Vandag is die meeste Afrikaners ondersteuners van die Demokratiese Alliansie, wat homself verbind het tot die handhawing en versterking van liberale waardes en wat as die opvolger van die Progressiewe Party van Helen Suzman en Van Zyl Slabbert beskou kan word. Hierdie steun spruit ongetwyfeld uit eie belang, maar dit neem nie die feit weg nie dat verskeie Afrikaners wat tans ' $n$ prominente rol speel op politieke gebied, en op terreine soos die regspleging, die akademie, die lettere en die godsdiens, liberale politieke opvattinge huldig. Afrikanerliberalisme is tans moontlik ' $n$ belangriker verskynsel as in die verlede, maar daar is tog 'n ontwikkelingslyn van liberale politieke denke onder Afrikaners, al was dit meesal tot 'n klein minderheid beperk, wat terug strek tot die agtiende eeu.

129 Vergelyk FA Mouton, Prophet without honour...

130 Vergelyk G Olivier, NP van Wyk Louw; literatuur, filosofie, politiek (Kaapstad, Human \& Rousseau, 1992), pp. 219-263. 